\title{
Pszichiátriai tünetekkel jelentkező neuroszifilisz négyéves utánkövetése
}

\author{
Tombor László dr. ${ }^{1}$ - Salacz Pál dr. ${ }^{1,2}$ \\ Jankelovics Éva dr. ${ }^{3}$. Hidasi Zoltán dr. ${ }^{1}$ \\ ${ }^{1}$ Semmelweis Egyetem, Általános Orvostudományi Kar, Pszichiátriai és Pszichoterápiás Klinika, Budapest \\ ${ }^{2}$ Jelenlegi munkahely: Fővárosi Önkormányzat Péterfy Sándor Utcai Kórház és Rendelőintézet, \\ Neurológiai Osztály, Budapest \\ ${ }^{3}$ MAZSIHISZ Szeretetkórház, Budapest
}

\begin{abstract}
A szerzők pszichiátriai tünetekkel járó neuroszifiliszes esetet közölnek. Az idősödő férfit zavart, kritikátlan viselkedés, mániform állapot és megalomán téveszmék miatt vettük fel az első alkalommal. Felvételkor jobb centrális facialis paresis, tremor és parkinsonismus volt észlelhető. Akut képalkotó és rutin laborvizsgálatok a tudatzavart egyértelmúen magyarázó eltérést nem igazoltak. A pszichiátriai kezelés hatására a delírium megszűnt. Ezután antipszichotikummal kezelt mániform állapot dominálta a képet, majd gyors kognitív leépülést és a motoros tünetek progresszióját észleltük. A koponya-MRI-vizsgálat corticalis és hippocampusatrophiát, fehérállományi hiperintenzitásokat talált. A liquorban pleocytosist, emelkedett összfehérjeszintet találtunk; a neuroszifilisz diagnózisát szerológiai vizsgálatokkal támasztottuk alá. Penicillinkezelést követően a kognitív tünetek enyhültek, a pszichiátriai tünetek remisszióba kerültek. Négy évvel a diagnózist követően a kognitív hanyatlás fokozatos progressziót mutat, a pszichiátriai tünetek relapsusa miatt két további alkalommal volt szükség osztályos felvételre.
\end{abstract}

Orv Hetil. 2018; 159(6): 234-238.

Kulcsszavak: neuroszifilisz, paralysis progressiva, pszichózis, tudatzavar

\section{Four-year follow-up of a neurosyphilis case presenting psychiatric symptoms}

The authors present a case of neurosyphilis associated with predominant psychiatric symptoms. The elderly man was admitted because of confused behavior, maniform state, lack of critical judgement and grandiose delusions. On admission, right central facial nerve paresis, hand tremor and parkinsonism were also found. Acute brain imaging and routine laboratory tests failed to identify a firm etiology of the confusional state. The psychiatric treatment resulted in complete recovery from delirium. Afterwards, maniform psychosis dominated the clinical picture for which antipsychotics were administered. Later, rapid cognitive deterioration and progression of motor symptoms were observed. MRI revealed cortical and hippocampal atrophy and white matter hyperintensities. Lumbar puncture found pleocytosis and elevated cerebrospinal fluid protein levels. Neurosyphilis had been confirmed by serologic tests. The cognitive symptoms improved and the psychiatric symptoms remitted under penicillin treatment. Four years after diagnosis, there is a gradual progression in the cognitive decline. Two additional hospitalizations were necessary due to the relapses of psychiatric symptoms.

Keywords: neurosyphilis, general paresis, psychosis, acute confusion

Tombor L, Salacz P, Jankelovics É, Hidasi Z. [Four-year follow-up of a neurosyphilis case presenting psychiatric symptoms.] Orv Hetil. 2018; 159(6): 234-238.

(Beérkezett: 2017. október 23.; elfogadva: 2017. november 26.)

\section{Rövidítések}

AKV = Addenbrooke-féle kognitív vizsgálat; HIV = humán immundeficientiavírus; MMS = mini mental state (mentális állapotot felmérő teszt $) ; \mathrm{RPR}=$ rapid plazmareagin; $\mathrm{TPPA}=\mathrm{Tr}$ - ponema pallidum partikulum aggregáció; VDRL = venereal disease research laboratory (nemibetegség-kutató laboratórium) 
A huszadik század elejéig az elmeosztályos felvételek egyik leggyakoribb okai a neuroszifilisszel összefüggésbe hozható mentális és viselkedészavarok voltak. Később az antibiotikumok felfedezése és elterjedése, a szifiliszes esetek korai szürése és ezzel összefüggésben a hatékony bőr- és nemibeteg-gondozói tevékenység hatására a kórkép prevalenciája drasztikusan csökkent. Ezzel együtt a döntően pszichiátriai tünetek képében jelentkező neuroszifilisz is irodalmi ritkasággá vált, a mindennapi osztályos gyakorlatban a betegségre való szürés is egyre kevésbé kap szerepet. Az utóbbi években a szifiliszes megbetegedések számának növekedését közlik [1]. Ez a trend Magyarországon is megfigyelhető [2], amit az epidemiológiai adatok mellett esetközlések is jeleznek $[3,4]$.

Lévén, hogy a szifilisz a pszichiátria klasszikus kórképe is, annak pszichés tüneteit lényegében a szakma minden úttörője összefoglalta. A betegség minden stádiuma járhat pszichiátriai tünetekkel, melyekről magyar nyelven talán Pethő tankönyve nyújtja a legrészletesebb összefoglalást [5]. A fertőzés primer szakaszában a betegség felismerése által kiváltott pszichogén reakciók, azaz reaktív szorongásos és hangulatzavarok alakulhatnak ki. A második stádiumban, meningovascularis forma esetén annak lokalizációjától és kiterjedtségétól függően fejlődnek ki tompasággal, levertséggel, memória- és alvászavarral járó reverzibilis organikus pszichoszindrómák. A harmadik szakaszra jellemző a paralysis progressiva, mely pszichiátriai szempontból dementiával, valamint az esetek jelentôs részében mániform állapottal, nagyzásos tébolylyal jár, tudatzavarral vagy a nélkül.

\section{Esetismertetés}

Az 59 éves férfit az első alkalommal ismeretlen ideje fennálló zavartság miatt a mentőszolgálat közterületről szállította osztályunkra 2013-ban. A beteg bejelentett lakcímmel nem rendelkezett, anamnézise ismeretlen volt, tóle állapota miatt nem lehetett megbízható autoanamnézist nyerni. Felvételekor térben és idôben dezorientált, agitált volt, figyelmét tartósan lekötni nem lehetett, hangulatát irritáltság, gondolkodását inkoherencia jellemezte, a felvételt megelőző eseményekkel kapcsolatosan konfabulált, amnéziás volt. Fizikális vizsgálatakor jobb centrális arcidegbénulást, mindkét kéz nyugalmi, durva hullámú tremorát, sudomotoros izgalmat és parkinsonismust észleltünk. Sürgős koponya-CT-vizsgálata több kisebb törzsdúci lacunát és leukoaraiosist írt le. Rutinlaborjában enyhén emelkedett retenciós paramétereket és enyhe mikrociter anaemiát találtunk, az EKG-n jobb Tawara-szár-blokkot láttunk. Láztalan volt. A tünetek alapján ismeretlen etiológiájú delirózus tudatzavarnak véleményeztük az esetet. Empirikus alapon tiamint, parenteralis folyadékpótlást, per os klonazepámot $(1,5$ $\mathrm{mg} / \mathrm{nap}$ ) és riszperidont (fokozatosan $3 \mathrm{mg}$-ig emelve) kezdtünk. Felmerült, hogy a tudatzavart alkoholmegvonás okozta, azonban a beteg negálta az etilfogyasztást, ráadásul ennek egyes tipikus jelei (potator küllem, obstrukciósenzim-emelkedés, macrocytosis stb.) is hiányoztak. A megkezdett gyógyszeres kezelés mellett a páciens tudata feltisztult, a továbbiakban a képet mániform, grandiózus pszichotikus állapot jellemezte. A beteg irritált, hyperthym, insomniás volt. Viselkedése kritikátlan, aktivitása céltalanul felfokozott volt, lazán rendszerezett, badar grandiózus téveszméket hangoztatott. Mindezek miatt a riszperidonkezelést változatlan dózisban folytattuk. A tudatzavar megszúnését követően, a mániform pszichotikus állapottal együtt középsúlyos kognitív deficit tüneteit észleltük, és bár téveszméi és mániás állapota riszperidon mellett jelentősen javult, az elkövetkező hetekben gyors progressziójú dementálódást és motoros teljesítményének markáns romlását észleltük súlyosbodó, aszimmetrikus felső végtagi dominanciájú rigorral, a kezek tremorával, akarattól független perioralis hyperkinesissel, valamint ekkor már ataxiával, dysmetriával és járásképtelenséggel. Motoros tüneteit sem az antipszichotikum dózisának csökkentése, sem adjuváns biperidén nem befolyásolta. Az ismételt laborvizsgálatok a normáltartományon belül voltak, a dementiairányú rutin laborvizsgálatok kórosat nem mutattak. A koponya MRI-vizsgálata a corticalis és a subcorticalis agyállomány csökkenését, mediotemporalis (hippocampus-) atrophiát és kisméretû fehérállományi hiperintenzitásokat igazolt (1. ábra). Lumbálpunkciót követően a liquorban pleocytosist (144/3, lymphocytákkal és monocytákkal), emelkedett összfehérjeértéket (199mg\%) találtunk. A szerológiai vizsgálatok az autoimmun encephalitist, a Borrelia- vagy HIV-fertőzöttséget kizárták, a szérum (RPR 1:128-ig pozitív) és a liquor (VDRL- és TPPA-pozitivitás) szerológiai vizsgálata szimptómás neuroszifiliszt igazolt. A két hétig folytatott $24 \mathrm{ME}$ intravénás penicillinkezelés lezárultával a páciens állapota a kezelést megelözővel egyező volt: súlyos dementia képét észleltük acalculiával, járásképtelenséggel és vizeletincontinentiával; produktív pszichotikus tünetek nem voltak jelen. Az antibiotikumkezelés lezárását követően a beteg krónikus belgyógyászati osztályra került, ahol változatlan gyógyszeres kezelés mellett komplex rehabilitációt, rendszeres gyógytornát kapott. A fogadó osztályon fél évig folyamatosan utánkövettük és konzultáltuk a beteget. A szérumRPR csökkenése megindult, ezzel együtt hat hónap elteltével a kognitív hanyatlás javulását láttuk, de a deficit teljesen nem szûnt meg, paralysis progressivát állapítottunk meg. Tartós antipszichotikumkezelés mellett pszichotikus relapsusa ekkor nem alakult ki. Önállóan tudott járni, continentiáját visszanyerte, enyhe, gyógyszeresen kezelhető parkinsonismus maradt vissza, a cerebelláris tünetek regrediáltak.

A fennmaradó kognitív tünetek és a betegség pszichotikus jellege miatt megtörtént a páciens gondnokság alá helyezése. Szociális anamnéziséből annyi volt feltárható, hogy elérhetó hozzátartozója nincsen, kettős állampolgárként, osztályos felvétele előtt ismeretlen időben települt vissza Magyarországra, bejelentett lakása nem volt, 


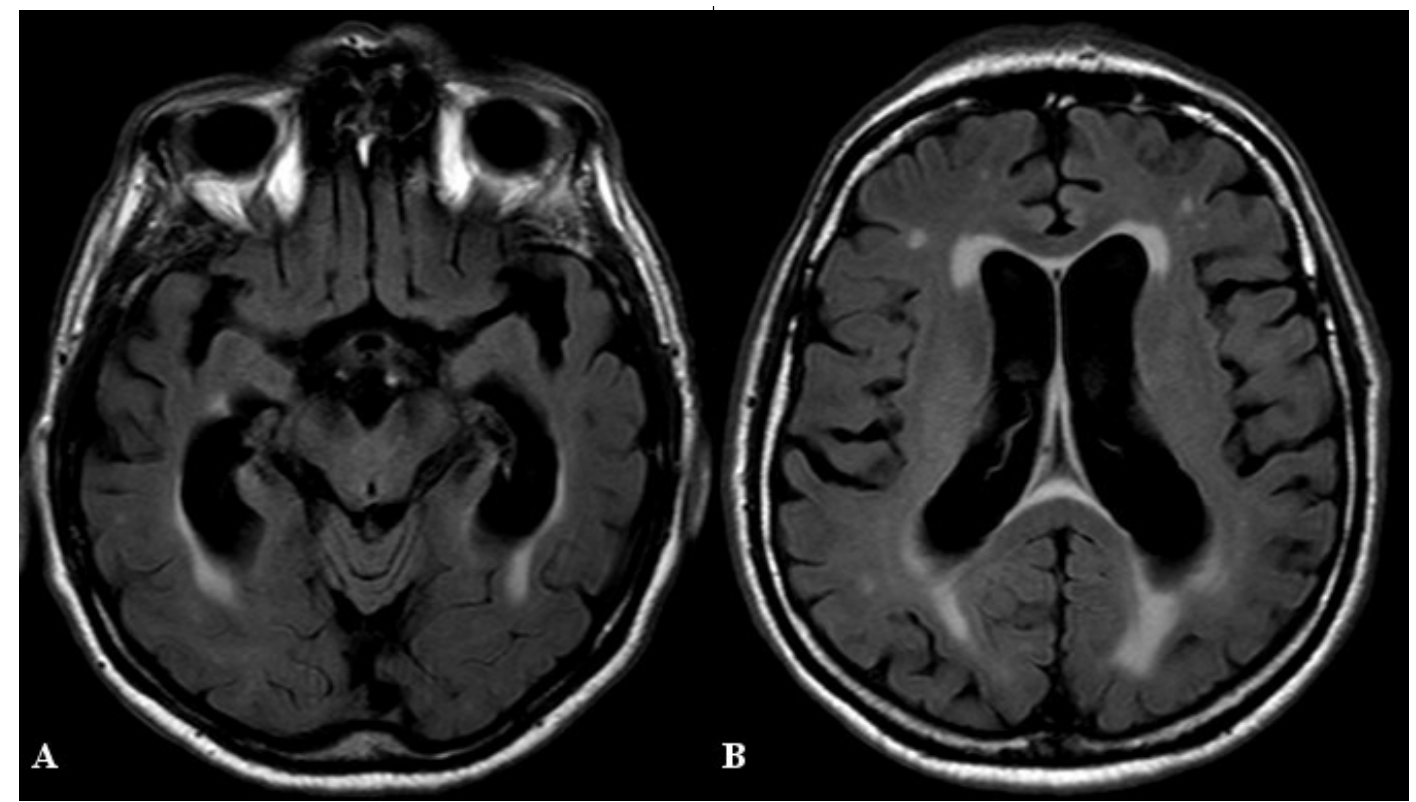

1. ábra

Agyi MRI képe két különböző horizontális metszetben a diagnóziskor (FLAIR-szekvenciák). A: Az oldalkamrák alsó szarvainak jelentős tágulata a mediotemporalis struktúrák sorvadásával és periventricularis hiperintenzitással. B: Corticalis atrophia képe periventricularis és mély fehérállományi hiperintenzitásokkal

ismerősöknél lakott, rendszeres szociális segélyt vett igénybe, bejelentett munkaviszonya nem volt, nyugdíjra itthon nem volt jogosult.

A második osztályos felvételére két évvel a neuroszifilisz diagnózisa után került sor, ismételten hanyatló kognitív status és irritált paranoiditás, ellenséges viselkedés miatt, amely a beteget tartósan ápoló rehabilitációs osztályon a rendszeres és gyakori pszichiátriai konzíliumok, terápiamódosítások ellenére progressziót mutatott. Motoros tünetei szintén újra progrediáltak: járászavar, incontinentia alakult ki ismét, beszéde dysarthriássá vált. A képalkotó vizsgálat a korábbinak megfelelő statust igazolt. A szerológiai vizsgálatok során a szérum-RPR és a liquor-TPPA korábbihoz képesti feleződését, lumbálpunkcióval emelkedett fehérjeszintet találtunk, sejtes elem nélkül. A romló klinikai kép és a nem megfelelő ütemú szerológiai titercsökkenés miatt a beteg ismételten antibiotikumkezelésben részesült az érvényes protokollnak megfelelően; pszichiátriai gyógyszerei változatlanok maradtak. A motoros és a pszichés tünetek további gyors progressziója megállt. Később a tartós antipszichotikumkezelés a beteget ápoló intézményben a hoszszas kompenzált állapot miatt elhagyhatóvá vált.

A harmadik, eddig utolsó pszichiátriai osztályos kezelésére a fentiekkel lényegében megegyező okok miatt került sor. A beteg viselkedése kritikátlanná, nyugtalanná vált, viselkedése paranoiditás miatt ellenséges volt, nemi szervét mutogatta, vizeletét és székletét inadekvát helyre ürítette. Ápolási osztályon a megemelt riszperidondózis ellenére sem volt tartható. A szerológiai vizsgálatok a legutóbbi antibiotikumkezelést követően kétszeres titer- csökkenést igazoltak, bár szeronegativitást nem. Ez alapján a legutóbbi antibiotikumkezelést eredményesnek minősítettük. A pszichés tünetekre a korábban bevált antipszichotikumkezelést tolerálhatatlan, súlyos extrapiramidalis tünetek miatt nem tudtuk visszaállítani, így végül váltás, olanzapin és a markáns hangulati töltet miatt valproát beállítása mellett döntöttünk, amelyek a nonkognitív tüneteket csökkentették, de remissziót nem tudtunk elérni, rehabilitációs osztályon való ápolása kritikátlan viselkedése miatt továbbra is csak jelentős nehézségek árán kivihető. Emissziójakor a páciensnél súlyos dementia állt fenn, etiológiai faktorként tercier szifiliszt állapítottunk meg.

A rendelkezésre álló szerológiai eredményeket és a dementia súlyosságát jellemző tesztpontszámokat az 1. táblázatban foglaltuk össze.

1. táblázat A páciens szérum-RPR-titerének és kognitív teljesítményének időbeli alakulása

\begin{tabular}{l|lllll}
\hline & Kiinduló & 3 hónap & 6 hónap & 27 hónap & 48 hónap \\
\hline Szérum-RPR & $1: 128$ & $1: 32$ & $1: 32$ & $1: 8$ & $1: 2$ \\
Liquor-TPPA & $1: 20480$ & NA & NA & $1: 10240$ & NA \\
MMS & 19 & 23 & 25 & 13 & 10 \\
AKV & 56 & 64 & 75 & 33 & NA \\
Órateszt & 5 & 6 & 4 & NA & NA \\
\hline
\end{tabular}

$\mathrm{AKV}=$ Addenbrooke-féle kognitív vizsgálat; $\mathrm{MMS}=$ mini mental state (mentális állapotot felmérô teszt); RPR = rapid plazmareagin; TPPA = Treponema pallidum partikulum aggregáció 


\section{Megbeszélés}

A szifiliszes esetek számának és a gondozási fegyelem lazulásának következtében egyes megbetegedések csak a késői szakaszban kerülnek felismerésre. A szifilisz korspecifikus morbiditása a fiatal, 20-35 év közötti, nagyvárosban élő férfiak körében a legmagasabb [2]. Páciensünknél az életkor nem tipikus lueszes megbetegedésre, de major mentális zavar első epizódjának megjelenésére sem. Negatív vagy bizonytalan pszichiátriai anamnézisú, marginalizált szociális helyzetú páciensek első elmeosztályos felvételekor szifiliszszerológiai vizsgálatot célszerú végezni, különösen, ha kognitív hanyatlás áll fenn, és ha a betegtól pszichés állapota miatt érdemi anamnézis nem is vehető fel. Bár a hazai elmeosztályok ilyen irányú gyakorlatáról nem áll rendelkezésre pontos adat, általánosságban elmondható, hogy a lueszszerológia rutinszerú elvégzésének gyakorisága mára sajnálatos módon lecsökkent, a nem specifikus szúrőtesztek általános elérhetősége és alacsony költsége ellenére. Esetünkben a fertőzés idejét, a lehetséges kontaktszemélyeket felkutatni nem lehetett. A páciens biográfiai adatait tekintve akár behurcolt esetról is lehet szó.

A nem kognitív tünetek szempontjából a késői neuroszifilisz gyakran mániás tünetegyüttes, prefrontalis lebenytünetek képében jelentkezik, melyrő́l számos adat áll rendelkezésre a nemzetközi irodalomban [6-8]. A páciens viselkedése tapintatlanná, kritikátlanná válik, korábban nem jellemzô megbotránkoztató viselkedésformák (trágárság, lopás, szeméremsértő magatartás stb.) jelentkeznek, indulatain nem tud uralkodni, gyakran ingerlékenység és eufória váltja egymást, jelezve a hangulati labilitást. A mániás állapot vegetatív jelei, insomnia, hyperbulia, valamint számos esetben megalomán, nagyzásos téveszmék jelentkeznek. Mindezek miatt a paralysis progressivát a bipoláris zavar mániás epizódjától kell elkülöníteni. Az utóbbira a fiatal, 30 év alatti kezdet jellemző, és többnyire az első kórházi felvételt szükségessé tevő epizódot több, sokszor szubklinikus hangulati epizód előzi meg, ezenkívül jellemzően depresszióval indul. Esetünkben a releváns pszichiátriai anamnézis hiánya utalhatott arra, hogy nem primer mentális zavarról van szó.

A kognitív tünetek frontotemporalis dementia képében jelentkeznek [9]. A kórfolyamat elején a deficit finom eltérések formájában van jelen, melyek az ítéletalkotást, a lényeglátást, a koncentrációt és az elvont gondolkodást érintik, egyidejűleg korai személyiségváltozással - ezt sokszor csak a heteroanamnézisból tudjuk feltárni. Késóbb a dementia memóriatünetei is egyre markánsabbá válnak, az amnézia jellegzetes időgrádienst nem mutat, a beteg az idóérzékét elveszti, majd a beszéd, az írás és az olvasás súlyos zavarai is jelentkezhetnek.

Mind a kognitív, mind a non-kognitív tünetek kialakulásában szerepet játszanak meningovascularis és parenchymalis krónikus gyulladásos folyamatok. Az előbbiek heveny vagy krónikus agyi ischaemia és ennek következményei, míg az utóbbiak sejtpusztulás és atrophia révén alakulnak ki, melyek a motoros, a szenzoros és az occipitalis kérget aránylag megkímélik [9]. Sajnálatos módon nem pontosan ismert, hogy mely tényezők jelzik előre a rossz prognózist a neuropszichiátriai tünetek szempontjából, bár az irodalom felveti, hogy a kedvezôtlen prognózis a felfedezéskor észlelt mediotemporalis atrophia súlyosságával áll összefüggésben [10-12]. Esetünkben már a páciens első észlelésekor mediotemporalis és globális atrophiát találtunk, illetve a kezelést követően, a progresszió átmeneti megtorpanásakor is acalculia maradt fenn, ami már a követési időszak kezdetén is jelen lévő paralysis progressivára utal.

A protokoll szerinti standard antibiotikumkezelés a kognitív és a non-kognitív betegségtünetek átmeneti javulását, évekig tartó relatív kompenzált statusát eredményezte. A pszichés tünetek az oki kezelésen túl a domináló mentális tünetegyüttesnek megfelelő pszichotróp kezelés beállítását kívánják meg. Az esetünknél beállított mindkét antipszichotikum (riszperidon, olanzapin) effektivitására van adat esetközlésekből [13-15]. A nemzetközi irodalmi adatok alapján eredményes kezelést követően is ritkán áll helyre a korábbi funkcionalitás [16, 17], ezért is kiemelkedően fontos a szifilisz célzott szúrése.

\section{Következtetés}

Esetünk érdekességét annak ritkasága, a változó epidemiológiai adatok tükrében pedig egyben aktualitása adja. Ezenkívül a szerzők hangsúlyozzák, hogy neuroszifilisz esetén a kognitív tüneteket mindig kíséri viselkedési (non-kognitív, pszichés) tünet, valamint hogy egyes esetekben ezek állnak a keresztmetszeti klinikai kép középpontjában. Negatív vagy ismeretlen pszichiátriai anamnézisű páciensek esetében, különösen, ha a pszichiátriai tünetegyüttes nem jellegzetes életkorban jelentkezik az első alkalommal, ha tudatborulás lép fel, vagy ha a tüneteket bármilyen neurológiai tünet vagy kognitív deficit kíséri, lueszszerológiai vizsgálatokat is célszerú végezni. Ez azért is hangsúlyozandó, mert bár a neuroszifiliszt hagyományosan a dementia reverzibilis etiológiai faktorának tartjuk, hosszabb távon a sikeres antibiotikumkezelés ellenére is progresszióra kell számítani. A luesz szisztémás jellege miatt az esetek multidiszciplináris szemléletet követelnek, beleértve a neuropszichiátriai és a szomatikus orvoslás együttmúködését is.

Anyagi támogatás: A közlemény megírása anyagi támogatásban nem részesült.

Szerzői munkamegosztás: A kézirat megírásában és a beteg kezelésében minden szerző részt vett. A cikk végleges változatát valamennyi szerző elolvasta és jóváhagyta.

Érdekeltségek: A szerzőknek nincsenek érdekeltségeik. 


\section{Irodalom}

[1] Fenton KA, Lowndes CM. Recent trends in the epidemiology of sexually transmitted infections in the European Union. Sex Transm Infect. 2004; 80: 255-263.

[2] Országos Epidemiológiai Központ. Sexually transmitted diseases Hungary 2013. 2nd half. [Szexuális úton terjedő betegségek Magyarország 2013 II. félév.] Epinfo. 2013; 38: 425-431. http:/ /www.oek.hu/oek.web?to=839,2557,2443\&nid=1261\& pid=1\&lang=hun [Hungarian]

[3] Tóth V, Hornyák Cs, Kovács T, et al. Meningovascular neurosyphilis as the cause of ischemic cerebrovascular disease in a young man. [Meningovascularis neurosyphilis miatti fiatalkori ischaemiás cerebrovascularis betegség.] Orv Hetil. 2011; 152: 763-767. [Hungarian]

[4] Wikonkál N, Nagy P, Tóth B, et al. Syphilitic glomerulonephritis: case report and review of the literature. [Veseérintettség syphilises fertőzésben: esetismertetés és a szakirodalom áttekintése.] Orv Hetil. 2015; 156: 32-35. [Hungarian]

[5] Pethő B. Comprehensive Psychiatry. [Részletes pszichiátria.] Magyar Pszichiátriai Társaság, Budapest, 1989; pp. 230-243. [Hungarian]

[6] Barbosa IG, Vale TC, de Macedo DL, et al. Neurosyphilis presenting as mania. Bipolar Disord. 2012; 14: 309-312.

[7] Hoffman BF. Reversible neurosyphilis presenting as chronic mania. J Clin Psychiatry 1982; 43: 338-339.

[8] Lin LR, Zhang HL, Huang SJ, et al. Psychiatric manifestations as primary symptom of neurosyphilis among HIV-negative patients. J Neuropsychiatry Clin Neurosci. 2014; 26: 233-240.
[9] Miklossy J. Alzheimer's disease - a neurospirochetosis. Analysis of the evidence following Koch's and Hill's criteria. J Neuroinflammation 2011; 8: 90.

[10] Kodama K, Okada S, Komatsu N, et al. Relationship between MRI findings and prognosis for patients with general paresis. J Neuropsychiatry Clin Neurosci. 2000; 12: 246-250.

[11] Hama K, Ishiguchi H, Tuji T, et al. Neurosyphilis with mesiotemporal magnetic resonance imaging abnormalities. Intern Med. 2008; 47: 1813-1817.

[12] Chen B, Shi H, Hou L, et al. Medial temporal lobe atrophy as a predictor of poor cognitive outcomes in general paresis. Early Interv Psychiatr. 2017 Apr 5. doi: 10.1111/eip.12441. [Epub ahead of print]

[13] Mirsal H, Kalyoncu A, Pekta Ö, et al. Neurosyphilis presenting as psychiatric symptoms: an unusual case report. Acta Neuropsychiatr. 2007; 19: 251-253.

[14] Taycan O, Ugur M, Ozmen M. Quetiapine vs. risperidone in treating psychosis in neurosyphilis: a case report. Gen Hosp Psychiatr. 2006; 28: 359-361.

[15] Turan S, Emul M, Duran A, et al. Effectiveness of olanzapine in neurosyphilis related organic psychosis: a case report. J Psychopharmacol. 2007; 21: 556-558.

[16] Beauchemin PR, Laforce R Jr. Neurocognitive changes in tertiary neurosyphilis: a retrospective chart review. Can J Neurol Sci. 2014 ; 41: 452-458.

[17] Margolin EG. Neurosyphilis: is it really a reversible cause of dementia? Geriatrics 2001; 56: 16.

(Tombor László dr., Budapest, Balassa u. 6., 1083 e-mail: tombor.laszlo@med.semmelweis-univ.hu)

\author{
Az Orvosi Hetilap 2018, 159, 40. oldalán (1. szám) megjelent OH-kvízre \\ egy helyes megfejtés érkezett. \\ A beküldő: Dr. Somogyi Erzsébet (Miskolc). \\ A nyertesnek szívből gratulálunk. \\ A nyereményét - egy, az Akadémiai Kiadó webáruházában \\ kedvezményes vásárlásra jogosító kupont - e-mailen küldjük el.
}

